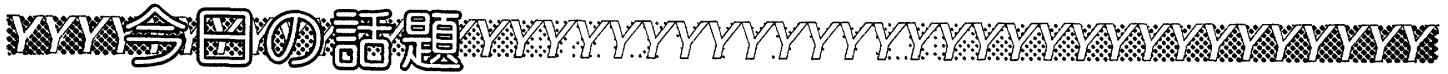

\section{プロリルエンドペプチダーゼ・インヒビターが示す 抗健忘作用}

\section{一バソプレシンの分解を阻害. 痴呆症薬への可能性}

近年, 医療技術の急速な進歩と新しい治療薬の開発に より，ヒトの寿命は著しい延びをみせている．総務庁の 発表によると, 本年度の日本人平均寿命は, 男 74.8 歳, 女 80.5 歳といずれる世界一の長寿国となっている。 た，65 歳以上の老年人口は 1,200 万人，総人口の $10.5 \%$ を占める.これはスエーデン，西ドイッに次ぐも ので, 2020 年には $23.5 \%$ に達し，世界一の高齢化国家 そなると推定されている，しかしながら，長寿を喜ぶ一 方で，高年齢になると体のあちこちに障害が現われてく るのが普通であり，そのうち特に深刻な問題が痴呆症の 増加である. 日本の統計では， 65 歳で約 $5 \%, 80$ 歳で は $20 \%$ の人に痴呆症状が見られるという.

高齢者の痴呆症には，脳血管障害型痴呆之老年性痴呆 (アルッハイマー型痴呆症)がある. 前者が卒中型で, い わゆる“ちゅらぶ”と呼ばれる症状であるのに対し，社 会問題化しているのが後者の “ぼけ”と呼ばれる老年性 痴呆症である.この老年性痴呆症はまた健忘症とも呼ば れ，記憶力の著しい減退以外はあまり身体に障害がな く, 特に短期の記憶の言失が著しく，自分を取り巻く環 境や，社会的ルールを思い出せないまま行動すること が，この症状を深刻な問題としている。このため，治療 法がなくわずかに脳代謝賦活剤の投与によって治療が 行なわれているのが現状である．筆者らは後述のよらな 理由から, 酵素阻害剤の痴呆症治療薬への可能性を追求 している(1,2).

痴呆症の病因は今のところ不明であるが，形態学的研 究や生化学的研究が最近活発化してきた. 断層診断法で みると, 痴呆症患者の脳が萎縮していることはよく知ら れている.また，シナプスや脳血管の周辺にアミロイド の蓄積が見られる，最近，このアミロイド遺伝子がクロ ーニングされ(3)，それが第 21 染色体上にあり，ダウン 症とよく似ていることが明らかになってきた、乙か し,このアミロイドの蓄積が原因なのか，杂れとも結果 なのかは不明である.
このように発症因子や機構は不明であるが，治療薬の 開発はすでに国内外の製薬会社で活発に行なわれつつあ る. その主たるものは GABA ( $\gamma$-アミノ酪酸) や TRH (甲状腺刺激ホルモン放出ホルモン) の誘導体などであ り、このなかにはフニラセタムやピラセタムなど臨床実 験まで進んでいるものもある.

一方，バソプレシンが記憶の改善に働くとの説があ る. バソプレシンは腎藏での水分の再吸収に㗢くペプチ ドホルモンであるが，デ・ウイード(5)をはじめいくつか の研究グループから,このホルモンが記憶の改善に働い ていることを示すデータが報告されている，たとえば, バソプレシンを遺伝的に欠損する尿放症ラットは記憶の 保持が悪く, バソプレシンの抗体を脳内に投与すると同 様の結果が得られる(6). またデ・ウイード(7,8)は, 脳内か ら HPLC でバンプレシンの分解物, $\mathrm{Pyr}^{4}-\mathrm{Asn}^{5}-\mathrm{Cys}^{6}$. $\left(\mathrm{Cys}^{1}\right)-\mathrm{Pro}^{7}-\mathrm{Arg}^{8}-\mathrm{Gly}^{9}-\mathrm{NH}_{2}$ [AVP(4-9) と略す]を得, この $\operatorname{AVP}(4-9)$ と $\operatorname{AVP}(4-8)$ を合成してその作用を調 ベ，これらが血圧上昇で見たバソプレシンの活性は示さ ないが，ステップスルー型受動的回避学習法ではバソプ レシンの $10^{3} \sim 10^{4}$ 倍もの抗健忘活性があることを明ら かにした. 彼は，バソプレシンは AVP(4-9) を経て $\operatorname{AVP}(4-8)$ へと分解され，これが真の記憶保持物質であ ると推定している.臨床的には，痴呆患者の䯣液中のバ ソプレシン量が正常人のそれより少ないことや，バソプ レシンの投与が治療に有効との報告もある.

筆者らは，プロリルエンドペプチダーゼを仔ヒツジ やウシの脳から精製し，酵素化学的性質を検討してき た(1). 興味あることに，この酵素はタンパク質や高分子 ペプチドにはまったく作用できず，バソプレシンのよう な 10 アミノ酸残基程度以下のペプチドによく作用して 不活性化することから，これら生理活性ペプチドの代謝 調節に関与することが推定された。これらのことから， “健康人では脳でのプロリルエンドペプチダーゼが正常 に働いているが，何らかの理由で調節機構が外れ，バッ 


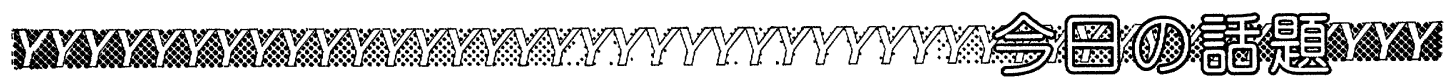

プレシンが必要以上に分解され，記憶保持に障害が現わ れる.したがって，治療には酵素活性を抑制すればよ い”と考えた.

筆者らは，酵素の基質特異性から酵素に特異的な阻害 剤を設計し，それぞれ特徵を持つ数多くの化合物を合成 して, ウシ脳酵素に対する上記化合物の阻害活性の強さ を調ベ，さらに二次スクリーニングとして動物実験を行 なった，記憶そのものの研究がようやく始まった段階で あり，ヒトの痴呆症と実験動物との差を充分考慮しなけ ればならないが，筆者らはスコポラミンで起こした実験 的健忘症ラットを用いた.

その結 果, $Z$-Gly-Pro- $\mathrm{CH}_{2} \mathrm{Cl}, Z$-Pro-prolinal, $Z$ Val-prolinal, Boc-Pro-prolinal などのプロリルェンド ペプチダーゼに特異的なインヒビターがその阻害力に相 関して抗健忘作用を示すのに対し，E-64，TLCK, アン チパインやペプスタチンなどのプロテフーゼ阻害剤には 抗健忘作用はまったく見られなかった。また，Z-Proprolinal 投与後, 脳内酵素活性が低下しているのを確認 した(1,2).

その後，筆者らの結果を追試するため，金戸らはマウ” スを使う独自の実験系を組み立てて調べた結果，まず， バソプレシンの記憶改善作用の再現性が確認された。次 いで，実験的に痴呆症を起こさせる方法としてスコポラ ミンまたは電撃ショックを用い, Y字迷路法, 能動的回 避学習法, 受動的回避学習法, レバー押し学習法などで 効果を検討した結果，いずれの方法においても上述のプ ロリルエンドペプチダーゼインヒビターが有効との結果 が得られている(9,10). このことは, 筆者らのデータを裏 づけるものである.

\section{花成誘導のメ力二ズム}

\section{—その物質的基礎を探る. 強光処理で蓄積するH fractionに興味}

光周反応によってつくられる花成ホルモンの存在が示 晙されてから，すでに半世紀を経たが，未だにその正体 は不明であり, 光周反応による花成誘導の物質的背景に 関しても，ほとんど何もわかっていない，しかし，最近 いくつか注目すべき報告が見られるので，ここではそれ らを紹介するとともに，筆者らが行なってきた仕事の概
その他，新規に化学合成された幾つかの化合物につい て, 酵素阻害活性と抗健忘作用との間に相関性が認めら れた ${ }^{(11,12)}$.このらちいくつかの化合物については, 経口 投与に和いても脳内での酵素活性が阻害され，抗健忘作 用が確認されている. また，インヒビター投与により， 脳内バソプレシン量の増加が見られている.

ヒトの健忘症にも効果があるかどうかは実際にヒトに 試みる以外に方法がないが，その前に毒性や副作用など の慎重な研究が必要である.

筆者らの研究はデ・ウイードらの説を支持する結果と なったが，このことにより神経科学の分野に新しい生化 学的アプローチが可能になったと考光ている.

1）芳本 忠: 農化誌, 58, 1147 (1984).

2) T. Yoshimoto, K. Kado, F. Matsubara, N. Koriyama, H. Kaneto \& D. Tsuru : J. Pharmacobio. Dyn., 印刷中.

3) D. Goldgaber, M.I.Lerman, O.W. McBride, U. Saffiotti \& D. C. Gajdusek : Science, 235, 877 (1987).

4) J.-M. Delabar, D. Goldgaber, Y.Lamour, A. Nicole, J.-L. Huret, J. De Grouchy, P. Brown, D. C. Gajdusek \& P.-M. Sinet : Science, 235, 1390 (1987).

5) D. De Wide \& B. Bohus: Nature, 212, 1484 (1966).

6) D. De Wide, B. Bohus \& Tj. B. van Wimersma Greidanus : Brain Res., 85, 152 (1975).

7) J.P. H. Burbach, G. L. Kovacs, D. De Wied, J. W. van Nispen \& H. M. Greven : Science, 221, 1310 (1983).

8) D.De Wied, O.Gaffori, J.M.van. Ree \& W. De Jong: Nature, 308, 276 (1984).

9）平 京子，金戸 洋：日薬理誌，89，243 (1987).

10）南理真人，金戸 洋: 日薬理誌，89，323 (1987).

11）樋口直樹, 橋本昌樹, 児玉 亨, 岩澤律夫, 川口直子, 斎 藤雅之, 深見治一, 田中隆治, 吉栖 㢣, 芳本 忠, 鶴 大典：日本農芸化学会昭和 62 年度大会講演要旨, p. 109 (1987).

12）斎藤雅之, 川口直子, 橋本昌樹, 桶口直樹, 深見治一, 田 中隆治, 吉栖 肇, 芳本 忠, 鶴 大典：日本薬学会第 107 年会講演要旨集, p. 620 (1987).

（芳本 忠, 鶴 大典, 長崎大学薬学部)
略を紹介する.

アメリカの Lay-Yee らは，短日処理を行なったアサ ガオ（花芽を形成する）と短日で光中断を行なったアサ ガオ（花芽を形成しない）の子葉から mRNA を抽出 し，それを用いて in vitro で合成させたポリペプチドの 電気泳動パターンを比較した. そして，短日処理を行な 
った子葉に特異的な mRNA があることを見いだしてい る.これは Flowering Newsletter に揭載された予報であ って, 詳細は不明であるが，この mRNAを用いた今後 の研究によって，花成ホルモンの実態あるいは花成誘導 のメカニズムに関する研究が大きく進展するかも知れな い.

スイスの Greppin, Bonzon らのグループは，短日条 件下で育てたホウンンソウ（長日植物）を連続照明下に 移すと, 限界日長 $(11 \sim 12$ 時間. 花成誘導に必要な最低 限の日長）を経た直後から葉のグルコース，フルクトー 大含量が増大し, それに伴って急激にエネルギーチャー ジや NADH/NAD 比が増大すること, さらにその 3〜 4 時間後には, 芽に打汸るペントース憐酸経路が活性化 されることなどを報告している(1). これらのことから， 彼らは栄養成長を支觉る代謝や構造（とくに膜）の再編 成によって花成誘導状態がつくられるものと考兄, 再編 成後にホルモンバランスの变化や花成遺伝子の活性化が 起こるのだろうとしている.

筆者ら（東大・農化, 高橋研と共同) は過去 10 年間 にわたって，アオウキクサを検定植物として，花成を誘 導する物質の探索を行ない，数多くの花成誘導物質を見 いだしてきた(2).すなわち，安息香酸およびその誘導体， ニコチン酸，ニコチンアミド，ピペュリン酸などであ る. しかしながら, これらの物質の植物体内含量は日長 の影響を受けず, これらが光周反応でつくられる花成ホ ルモンであるとは考号れないまた，これらの物質の 作用はアブシジン酸，ジベレリン，インドール酶酸によ って抑制され，サイトカイニンによって促進されること が明らかにされたが，これら植物ホルモンの体内含量も 日長によってあまり変化せず，これらが光周反応に関与 するとも考党られない(2).

しかしながら，安息香酸やニュチン酸はごく短時間の 処理で有効に働き，これらの物質が花成誘導活性を有す ることは否定できない，そこで，筆者らは，光周反応に よる誘導と安息香酸による誘導とは異質のものではない かと考穴ている. アオウキクサに対して，高濃度の鉄 は，短日効果を促進するが，安息香酸の効果には洼とん ぞ影響を与えず, 高濃度の鉄の存在下で安息香酸を与え ると短日効果と安息香酸の効果とが加算的に現われるこ
ともこの考光を支持する.

アサガオは短日植物であるが，13〜 $14^{\circ} \mathrm{C}$ の低温が 10 日以上与えられると連続光下でも花芽を形成する．とこ ろが，23C で 15,000 ルックス以上の強光を 3 日間与え た直後であれば，3〜 5 日間の低温 $\left(13 \sim 14^{\circ} \mathrm{C}\right)$ に反応し て花芽を形成し，この 3 日間の強光処理は，安息香酸そ の他アオウキクサの花成を誘導する物質の供与によって 置きかえられる、興味あることに，この強光中に未同定 の物質 $\mathrm{H}$ fraction が子葉中に蓄積され，フェニルアラ ニンアンモニアリアーゼ (PAL) の阻害剤であるアミノ オキシ酢酸 (AOA) は, この物質の蓄積を阻害するのみ ならず強光の花成誘導効果をも打ち消す（篠崎ら，未発 表)、また，いろいろな条件下で $\mathrm{H}$ fraction の蓄積とそ れに続く低温の花成誘導効果との間に高い相関が認めら れるし，低温期間中にも，徐々にではあるが $\mathrm{H}$ fraction の蓄積がみられる，そして，低温処理中に与えた $\mathrm{AOA}$ も $\mathrm{H}$ fraction の蓄積を抑制すると同時に花成を抑制す る. 特そらく，低温による花成誘導の初期段階として H fraction の蓄積が必要なのであろう. そして, 強光処理 はこの物質を急速に蓄積させることによって花成に必要 な低温処理期間を短縮するものと考兄られる.

抽出された $\mathrm{H}$ fraction は大変不安定であるため, こ の物質が何であるかはまだ同定されていない、しかし， $2 \%$ の熱酢酸で抽出されることや，その蓄積が AOA に よって阻害されることなどから考劣ると，この物質はフ ェノール類またはそれに関連したものである可能性が強 い.

アサガオは，低温のみならず貧栄湌で培養された場合 にも連続光下で花芽を形成し，その際子葉中に多量のク ロロゲン酸を蓄積する、そして, 子葉中のクロロゲン酸 含量と花成との間には常に高い相関が認められ，AOA はクロロゲン酸の蓄積を阻害するのみならず, 貧栄養に よる花成をる阻害する (篠崎ら, 未発表).

このように, 低温, 貧栄養によるアサガオの花成誘導 はいずれも AOA で阻害され，これらの誘導過程には フェノール類の代謝が関与するものと考学られるが, AOA は短日によるアサガオの花成にはまったく影響を 与えない。したがって，アサガオに対する低温や貧栄養 の作用も，アオウキクサに対する安息香酸の作用と同じ 


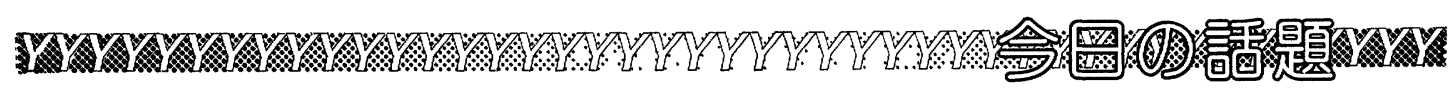

く，短日効果と区別すべきものであろらと考觉られる. 低温や貧栄養による花成誘導はアオウキクサですしばし 岒認められるのであって，今後はこれらと安息香酸類の 作用との関係を詳しく調べることが必要であろう．

以上のような考孚に対して，貧栄養による花成と短日 処理による花成とは密接に関連したものであることを示 㕬する報告(3) むる. アオウキクサ 6746 (短日植物) は 貧栄養にすると連続光下でも花芽を形成するが，培養液 中の窒素源を減らすだけ，あるいはアンモニアを含まな い培養液であれば，硝酸還元酵素の阻害剂を与えるだけ でる花芽を形成する. 暗所では硝酸還元酵素の活性が急
速に低下すること，敃よび硝酸還元を強く阻害するシア ンを毎日 17 時間与えればこの植物は花芽を形成するこ となどから，田中( ${ }^{(3)}$ は短日効果の少なくとも一部は長い 暗期による窒素代謝の阻害に基づくものと考えている. ただし，硝酸還元酵素の阻害剤による花成誘導がみられ るのは, アオウキクサの系統 6746 のみである.

1) M. Bonzon, M. Hug, E. Wagner \& H. Greppin : Planta, 152, 189 (1981).

2) 藤岡昭三 : 遺伝, 40(5), 45 (1986).

3）田中 修: 遺伝, 40(8), 23 (1986).

(瀧 本 敦, 京都大学農学部農林生物学科)

\section{哺乳類精子の活性化のシグナル}

\section{一重炭酸イオンが引き金. アデニレートシクラーゼを活性化}

哺乳類の精子は，受精に至るまでに少なくとも 2 回の 活性化をうける.すなわち，精巣で形成された精子は精 巣上体に運ばれ，そこを通過する間に成熟して運動と受 精の潜在的な能力を獲得する. しかしながら, 精巣上体 尾部に蓄えられている間は, 精子の運動性る代謝活性も 共に低く保たれている．射精により精子は運動を開始 し，また代謝も京進する. これが第一の活性化である.

しかし, 射精直後の精子の受精能は完全ではなく, 通常, 雌の子宮あるいは輸卵管に和いて, 受精能獲得 (capacitation) といら変化を受けて初めて受精可能とな る.この過程の詳細はまだ明らかではないが, 細胞表層 や細胞膜の変化と相まって, 細胞内部でも代謝などに変 化が起こり, その結果, 受精能を獲得しているらしい. これが第二の活性化であり,やはり運動性や代謝活性の 上昇が認められる. 精子は, これらの活性化が完了して 初めて先体*反応 (卵由来の 特定の物質の作用によって 先体が急速に変化すること. 受精に関与する酵素系の放 出も同時に起こる）を起こし，受精可能となる.

では，何がこれらの活性化を起こす引き金となってい るのであろらか. 現在までに調べられたほとんぞすべて の種に括いて, 精子内サイクリック AMP (cAMP) レ ベルの上昇が両活性化に際して, あるいは先駆けて認め られている.このことは, cAMP を介した何らかのメカ

\footnotetext{
*多くの動物の精子の頭部先端にある細胞器官
}

ニズムが活性化の担い手となっていることを示唆してい る. 実際, CAMP の分解酵素であるホスホジェステラー ゼ (PDE) の阻害剤を精子に加えると, 細胞内の cAMP レベルの上昇とともに，代謝と運動性の促進や capacitation の速度の上昇が観察される.

ところで, 精子内の cAMP レベルが合成酵素である アデニレートシクラーゼ (AC) と PDE の活性のバラン スによって調節されていることは体細胞と同じである が， AC の活性調節機構が 精子では大きく異なってい る. すなわち, 体細胞で認められる GTP-依存性調節タ ンパク質のらち少なくとも Ns タンパクを欠いており, また触媒ニニットそのものの性質も体細胞のものとは異 なっている. そのため, 体細胞でのホルモンに相当する 1 st メッセンジャーの存在も確認されていない. これま でに, 精子の AC の活性化因子の候補として広く指摘さ れてきたものはカルシウムイオン $\left(\mathrm{Ca}^{2+}\right)$ である. 確か に, capacitation の際に $\mathrm{Ca}^{2+}$ が精子の運動を高めるこ とが報告されているし，先体反応には不可欠なイオンで はあるが，動物種や実験条件によって AC に対する作用 は異なり，一定していない.

一方, 精巣上体尾部液中で精子が低活性に保たれてい る原因と考えられてきた高細胞密度, 尾部液の粘性, 低 酸素分圧，呼吸基質の欠如，低 $\mathrm{pH}$ ，高浸透圧などをす べて解除しても，射出精液中での高い運動性や代謝活性 


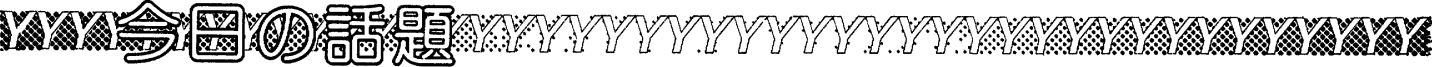

には及ばないこと，また射精に伴って精子の cAMP レ ベルが上がることは，副生殖腺分泌液の中に精子の活性 化に必要な因子が含まれていることを示している.

筆者らは，ブタの精漿中に精巣上体尾部精子の AC を 活性化して運動や呼吸を促進する因子を見いだし，分離 精製したところ，重炭酸イオンであることがわかった。 精漿から重炭酸イオンのみを除くと精子を活性化する作 用がなくなること，再添加によってそれが完全に回復す ることから，重炭酸イオンが射精による精子の活性化の 引き金になっていることが推察された，さらに，精巣上 体尾部液の重炭酸イオン濃度は $2 \mathrm{~mm}$ と非常に低く, 射 精時に精襄から分泌された重炭酸イオンによって精液中 の濃度は 20〜30 m に上昇する.すなわち，射精に伴 って精子外液の重炭酸イオン濃度は約 10 倍に増大する ことになる. 重炭酸イオンによる $\mathrm{AC}$ の活性化や運動と 呼吸の促進が数 $\mathrm{mm}$ から起こり始め, 半作用濃度が約 $18 \mathrm{~mm}$ であることを考劣ると，この濃度変化によって第 一の活性化は十分説明できる.ささらに, この重炭酸イオ ンの作用はブタに限らず調べた限りすべての哺乳動物で 認められる ${ }^{(1 \sim 3)}$.

さて，重炭酸イオンが精子の運動や代謝を促進するこ とは古くから知られていたが，このイオンが生体の最も 重要なバッファー系をなしていることから，活性化のシ グナルとしては捉えられていなかったようである．しか し，上述のように少なくとも第一の活性化に関しては， 重炭酸イオンは AC を直接活性化することによって㗢 いていることがわかった(3). これまで，種々の精子の反 応を解析するメディウムには，すでに重炭酸イオンがバ ッファーとして含まれている場合がほとんとで，そのよ うな条件で反応に必要な因子を検索しても，重炭酸イオ ンが見逃されるのは当然であった。

最近，この点を見直した報告が幾つか見られるように なり(4)，アデノシンや $\mathrm{Ca}^{2+}$ が精子の cAMP レベルを上 げる場合にも重炭酸イオンの共存が必要であることが明 らかになっている，さらに，重炭酸イオンが存在しない と，マウスの精子の先体反応が完全に起こらなくなると ともに, capacitation も著しく抑制されることも報告さ れた. このことは, 子宮体液や輸卵管液の重炭酸イオン の濃度が $40 \mathrm{~mm}$ 以上にもなっていることを考觉ると，
第二の活性化でも重炭酸イオンが調節因子として主要な 役割を果たしていることを示していると考えられる．こ のよらに，血中レベルとは明らかに独立して調節されて いる精子外液の重炭酸イオン濃度の変化こそ, 精子の活 性化の主要なシグナルになっているのではなかろらか.

このことは，逆に，重炭酸イオンレベルの異常によっ て精子の活性化が十分に起こらない場合が生じることを 意味する、たとえば，男子不妊症には精子の運動不全を 伴っている場合があるが，患者の精子の精液中の運動性 と重炭酸イオンレベルとの間に正の相関が認められた. また，同一の患者で精液中の運動性の改善が見られる場 合には，ほとんど例外なく重炭酸イオンレベルも改善さ れていた，運動不全の原因の中には，精子の運動能は本 来備わっているにもかかわらず, 精液の重炭酸イオンレ ベルが低いために，AC の活性化が不十分で運動性が悪 くなっているものがあると言える(5).

重炭酸イオンは直接 $\mathrm{AC}$ 分子に作用していると思わ れるが，このような例はある種の分泌顆粒膜の $\mathrm{Mg}^{2+}$ ATPase の重炭酸イオンなどの陰イオンによる活性化の 際にも認められ(6)，精子の AC だけに特異的なものでは ないようである.いずれにしても，細胞膜の内側にある AC を活性化するわけであるから，精子の細胞膜を介し た重炭酸イオンの輸送系の解析が今後の課題となる．ま た，十分に呼吸基質があれば，一旦精子が活性化される と, 細胞内で発生した $\mathrm{CO}_{2}$ により重炭酸イオンが補わ れることによって AC は活性状態が保たれ，精子の活性 も維持される ${ }^{(3)}$. 細胞膜にあるプロテアーゼと精漿由来 のインヒビターとの相互作用も，この AC の活性維持 に関与しているらしい(7). 本稿では触れなかったが， cAMP レベルの上昇が精子の活性化に結びつくまでの 過程の解析も，今後に残された課題である.

終わりに，本稿執筆の機会を与えて下さった杉田良樹教授（筑 波大学基礎医学系) に深謝いたします.

1) N.Okamura \& Y.Sug1ta : J. Biol. Chem, 258, 13056 (1983).

2) N. Okamura, Y. Tajima, A. Soejima, H. Masuda \& Y. Sugita : J. Biol. Chem., 260, 9699 (1985).

3) Y. Tajima, N. Okamura \& Y.Sugita: Biochim. Biophys. Acta, 924, 519 (1987).

4) 岡村直道, 田島 裕, 杉田良樹: 実験医学, 4, 937 (1986).

5) N. Okamura, Y. Tajima, H. Ishikawa, S. Yoshii, K. Ko1so \& Y.Sugita : Fertil. Steril., 45, 265 (1986). 


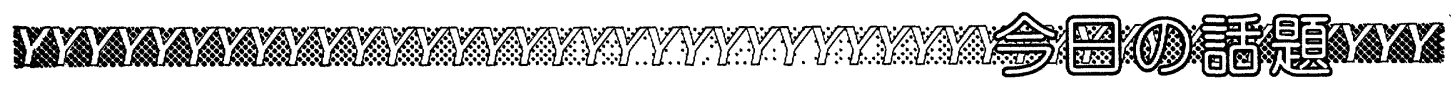

6) M. Y. Lorenson, Y.-C. Lee \& L.S. Jacobs : J. Biol. Chem., 256, 12802 (1981).

7) N. Okamura, Y. Tajima \& Y. Sugita : Develop. Growth
\& Differ., 28, supple., 85 (1986).

(岡村 直道, 筑波大学基礎医学系)

\section{アスピリンはなぜ胃に悪いか}

\section{一一胃壁保護作用を有する粘液糖蛋白質の動態との関わリ}

Prout による胃内塩酸の発見 (1824 年) や, 胃酸存在 下で活性型となる蛋白質分解酵素ペプシンを胃組織が分 泌することを明らかにした Schuwann の研究(1836 年) などにより，19世紀の初めにはすでに胃という器官が 生体の中では非常に特殊な性格を有していることが知ら れていた. 以来, 自己が分泌する組織腐食性物質である 塩酸やペプシンに対する生体の示す強い抵抗性は謎であ り，かつ興味ある研究対象となってきた. 現在, この抵 抗性の根拠としては, (1)細胞の代謝回転（胃粘膜の被覆 上皮細胞は数日で剥離して新生し, 胃粘膜の恒常性を維 持していると考兄られている), (2)粘膜血流 (胃粘膜組 織は毛細血管が発達し, 栄養や酸素の供給とともに傷害 性物質を速やかに血管内にとり込み，希釈と胃組織から の除去を行なっていると考えられている)，(3)粘液（物 質透過の障壁となり, 粘膜上皮細胞の表面を覆って傷害 性物質との接触を阻止している) などが考えられてい る. しかしながら，それらの抵抗性も絶対的なものでな く, 生体の種々の変化, いわゆるストレス状態などや, 種々の薬剤の服用などにより胃壁が破壞され潰瘍を生じ ることが知られている. 本稿では, 実験動物のラットを 材料にした筆者らの最近の知見をまじえ，粘液を中心に アスピリンの胃粘膜傷害作用に関して紹介したい。

胃粘液は胃粘膜の被覆上皮細胞および胃底腺・幽門腺 の副細胞が分泌する粘稠性の液体であり, 粘液の主体を なすのはムチンと呼ばれる糖蛋白質である. ムチンは粘 液糖蛋白質とも呼ばれ, 胃に限らず消化管・呼吸器・生
殖器などの上皮細胞により産生分泌され, 糖蛋白質の中 でもニニークな性質を持った一群を形成している.すな わち, 分子量が $2 \sim 44 \times 10^{6}$ ときわめて巨大な分子であ ること，糖鎖は蛋白質のセリンあるいはスレオニンにア セチルガラクトサミンが結合した Oーグリコシド型の 結 合よりなり，糖鎖の長さは二糖から長いもので二十数糖 よりなること, 糖鎖は非常に多様性に富み, 血液型のエ ピトープを含み, 糖の一部は硫酸化されていることなど が挙げられる. また, 糖含量が全重量の約 8 割と非常に 糖鎖に富むことから，㔻白質ュアーに糖鎖が百足の足状 に多数結合した形状が想定されている.

ところで, 組織化学的手法で胃組織を染色することに より，胃のムチンは硫酸基を有するスルホムチン，シア ル酸含量の高いシアロムチン, フコースの含量が高いフ コムチンなどに識別しうることが知られているものの, 粘液糖蛋白質は巨大分子で粘性が高いため，生化学的な 取扱いが非常に困難で, 分子種を異にする粘液糖蛋白質 の研究は遅れている. 筆者らは，これまでの検討の結 果, 胃酸やペプシンを分泌する胃底腺を有する胃体部 と, 主に粘液を産生する幽門腺を有する前庭部とから得 られる粘液糖蛋白質は種々の点で非常に相違しているこ とを明らかにした(1). 両部位より得られる粘液楉蛋白質 は分子量が $4 \times 10^{5}$ から $6 \times 10^{6}$ 以上と, 多分散系で, ア ミノ酸組成, 糖含量および糖鎖を構成する糖の種類など はほぼ同一であるが, 糖鎖の平均的な長さ, 構成糖の組 成比拈よび硫酸化の程度が表に示したように相違を示す.

粘液糖 蛋白賈の組成

\begin{tabular}{|c|c|c|c|c|c|c|c|c|}
\hline & \multicolumn{6}{|c|}{ (GalNAcol に対するモル比) } & \multirow{2}{*}{$\begin{array}{l}\text { 硫 酸 化 } \\
\text { エステル } \\
\text { (重量\%) }\end{array}$} & \multirow{2}{*}{$\begin{array}{l}\text { 蛋 白 質 } \\
\text { (重量\%) }\end{array}$} \\
\hline & GalNAcol & GalNAc & GlcNAc & Gal & Fuc & NANA & & \\
\hline 胃 体 部 & 1.0 & 0.2 & 4.8 & 4.3 & 1.9 & 0.3 & 0.2 & 22.6 \\
\hline 前 庭 部 & 1.0 & 1.9 & 4. 8 & 3.3 & 3.1 & 0.1 & 0.04 & 22.2 \\
\hline
\end{tabular}

GalNAcol : N-アセチルガラクトサミニトール, GalNAc : N-アセチルガラクトサミン, GlcNAc : N-アセチルグルコサミン, Gal : ガラクトース, Fuc : フコース, NANA : N-アセチルノイラミン酸 


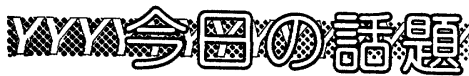

また，粘液糖蛋白質は，蛋白質分解酵素に対して耐性 を示す分子量にして $4 \sim 5 \times 10^{5}$ 程度の大きさの糖鎖に覆 われた基本ニニットよりなり，基本ニニットがジスルフ ィド結合や蛋白質部分を介して巨大分子を構成している と言われている．胃体部より得られる粘液糖蛋白質は前 庭部に比較して蛋白質分解酵素の分解を受けにくく，乙 かもジスルフィド結合の還元処理によっても低分子化し ない部分を含む。

機能的には粘液糖蛋白質のうち硫酸化されたものは， 蛋白質と結合してペプシンの消化から基質を保護する働 きをすることが知られているが，この抗ペプシン作用は 硫酸基を多く持った胃体部より得られる粘液糖蛋白質に は認められるが，前庭部より得られるものには認められ ない，現在のところ部位による粘液糖蛋白質の相違の意 義は推定の域を出ていないが，胃体部粘膜の粘液糖蛋白 質の硫酸化度が高いことは，胃底腺細胞をペプシンの攻 撃から守るとともに，一種のイオン交換樹脂としてプロ トンの胃底腺深部から胃内腔への輸送のための水路を形 成していると推測され，また胃体部の粘液糖蛋白質が低 分子化しにくいことは, それらの機能維持強化に, より 有利な状況をつくるものと思われる.

ところで，アスピリンがヒトをはじめ種々の動物に胃 粘膜傷害を発生させうることは古くから知られていた。 イヌ、ネコ、ラット，マウスなどの実験動物に容易に胃 粘膜傷害を作製しうることにより，これをで潰瘍の成因 解明および抗潰瘍薬の薬効判定にアスピリンによる実験 潰瘍が利用されてきた. ラットにアスピリンを経口投与 （100～300 mg/kg）すると, 数時間の内に胃粘膜の表面, 主として胃体部にびらんを生じる．場合によっては，出 血斑を伴い，出血部位が線状に広がることもある．これ らの粘膜傷害は，アスピリン投与後 5〜7 時間目より回 復に向からことが知られている。また, 組織化学的に観 察すると，表在性のびらんよりは遅れて出現する腺の深 部にまで達する深い亀裂が見られ，この回復には数日間 を要すると言われている(2). また，アスピリンは弱酸性 物質であり，酸性下ではイオン化されず脂溶性を示し， 粘膜障壁の脂質層を通過して胃粘膜組織に吸収され，細 胞毒性を発揮すると言われているが，酸性溶液ととるに 投与すると，より低用量です傷害が出現する，以上は，
アスピリンの単回投与による急性実験であるが，アスピ リン $(250,500 \mathrm{mg} / \mathrm{kg})$ を 1 日 1 回，6 カ月間連続投与 することにより，ヒトの慢性潰瘍に類似した潰瘍を作製 しらることが報告されている(3).

それでは，アスピリンはいかなる様式で胃粘膜傷害を ひき起こすのであろらか。アスピリンの作用機序として は, 脂溶性の弱酸であることから酸化的リン酸化の脱共 役剈として作用すると考兄られていたが，近年は種々の 酵素のアセチル化による酵素阻害作用, とりわけプロス タグランジンの合成酵素であるシクロオキシゲナーゼの 非可逆的阻害によりその薬理作用が説明されている. 胃 粘膜の防御に関しても, 種々の胃粘膜傷害性物質によっ てひき起こされる傷害が，プロスタグランジンを前もっ て投与することによってほとんど完全に防止しうること が知られており，この現象はプロスタグランジンの細胞 保護作用（サイトプロテクション）と呼ばれ，胃粘膜防 御に和けるプロスタグランジンの重要性が注目される所 以である.

筆者らも，プロスタグランジンが粘液糖蛋白質の生合 成および分泌を促進するという結果をすで発表してい る(4). しかしながら，アスピリンと同種の非ステロイド 系抗炎症剤であるインドメサシンが，胃粘膜のプロスタ グランジンの生合成を完全に抑制する用量ですそれだけ では胃粘膜に傷害を発生させないことから，粘膜内のプ ロスタグランジンの減少が粘膜抵抗性の減弱を意味する としても，傷害発生の直接の引き金とは考学にくい，

筆者らはこれまでの検討により，アスピリンによる胃 粘膜表面の傷害発生に先行して粘膜内の粘液糖蛋白質ふ 減少を示すことを明らかにした(5).すなわち，アスピリ ン投与 1 時間後より粘膜中の粘液糖蛋白質は減少し， 3 時間後には無処理群の $50 \%$ 近くにまでなり，以後は徐 徐に回復に向から，一方，粘膜表面の傷害は 3 時間目よ り顕著となり， 5 時間後で最も增悪し，以後快方に向か う. 最近の Slomiany らの報告によれば, アスピリンは 直接粘液糖蛋白質に作用し, 蛋白分解酵素に対する感受 性を増加させるという(6). こうした点を併せ考劣ると， アスピリンにより粘液糖蛋白質は何らかの構造変化を受 け，ペプシンにより速やかに分解をらけて低分子化し， 粘性の低下を招いて胃組織から消失し, 以上の結果, 粘 


\section{W}

膜表面が露出し, びらんおよび出血性の線状潰瘍をひき 起こすものと解释される.

また，筆者らは，粘液糖蛋白質の生合成に対するアス ピリンの影響を検討し，胃体部の粘液糖蛋白質の硫酸化 が最も抑制されるという結果を昨年の生化学会で発表し た. 今年のアメリカ消化器病学会で Slomiany らも, ア スピリンにより硫酸基の転移酵素が抑制されることを報 告している.これらの実験結果は, アスピリンによりひ き起こされる胃腺深部に発生する傷害を説明し得ると考 える.すなわち，胃底腺深部での粘液糖蛋白質の硫酸化 の低下は, プロトンの水路の破壊, ペプシンによる胃底 腺細胞の攻撃に対する防御能の低下などを招き，胃底腺 深部に及ぶ亀裂が生じるものと推測できる．いずれにせ よ，アスピリンによる胃粘膜傷害の発生については, (1)
粘液糖蛋白質に対する直接的作用，(2)粘液糖蛋白質の硫 酸化抑制，(3)プロスタグランジンの合成阻害, (4)酸化的 リン酸化の阻害によるエネルギー供給の停止など, 粘液 糖蛋白質の動態に関する諸要因が複雑に絡み合い潰瘍発 生に至るものと考光られる。

1) S. Ohara, K. Ishihara \& K. Hotta : Comp. Biochem. Physiol., 83 B, 273 (1986).

2) N.D. Yeomans, D. J.B. St John \& W.G. R.M. de Boer : Am. J.Dig. Dis., 18, 773 (1973).

3) D. J. B. St John, N.D. Yeomans \& W. G. R. M. de Boer : Gastroenterol., 65, 634 (1973).

4) 桑田 肇, 石原和彦, 小原 進, 筧 正雄, 勝山 努, 岡 部治弥，堀口恭子：日消誌，83，2310 (1986).

5) Y. Azuumi, S. Ohara, K. Ishihara, H. Okabe \& K. Hotta : Gut, 21, 533 (1980).

6) J. Sarosiek, K. Mizuta, A. Slomiany \& B. L. Slomiany : Biochem. Pharmacol., 35, 4291 (1986).

(小原 進, 堀田恭子, 北里大学医学部生化学教室)

\section{サンゴ礁生物における麻瘴性貝毒の動態}

\section{一一毒の構造変換を行なう細菌を発見}

麻痺性貝毒と総称される一群の毒 (paralytic shellfish poison, PSP) はフグ毒のテトロドトキシンに匹敵する 急性毒で，海産毒の中でもきわめて高い注意を必要とす る. これまで, 多くの研究者によって毒の分布, 化学構 造, 毒化機構, 薬理作用の解明が精力的に行なわれて きた ${ }^{(1,2)}$. 毒の本体として最初に単離構造決定された saxitoxin (STX) を基本骨格とし, STX N-1 位の-OH, C-11 位の $\alpha, \beta-\mathrm{OSO}_{3}^{-}$，カルバモイル基の $-\mathrm{SO}_{3}{ }^{-}$など の置換基の有無により，現在までに比毒性を異にする 12 種の類縁体の化学構造が明らかにされている(3).

毒化機構の解明は，まず二枚貝についてなされた，温 寒帯域では Protogonyaulax 属（旧 Gonyaulax 属の一 部), 熱帯域では Pyrodinium bahamense var. compressa などの渦鞭毛藻が毒を生産することが知られている(1,4). 一方，サンゴ礁域ではカニを原因食品とする高死亡率の 食中毒の発生があり，橋本らによってオウギガニ科 3 種 炕高含量の STX が検出されたが，毒化原因は不明であ った．筆者らは，橋本らと同じく沖縄サンゴ礁で採集し たヤコウガイなどの巻貝の内臟から STX を主成分と する PSP を検出し(5)，これを契機にサンゴ礁生物の PSP の毒化機構を追求した。本稿では，その過程で見
いだした細菌によるPSP の構造変換 ${ }^{(6,7)}$ を心に紹介す る.

巻貝やカニは二枚貝とは異なり，プランクトン食性で はない.カニは雑食性であるが巻貝は藻食性なので, 共 通の食物連鎖があるとすれば，海藻の可能性が高いと考 えた、そこで，毒化したカニが生息している石垣島川平 のリーフで採集した海藻 18 種の毒性試験を行なったと ころ，モサズキ属の紅藻石灰藻 Jania sp. から PSP が 検出された. 毒組成は gonyautoxin $1,2,3\left(\operatorname{GTX}_{1,2}\right.$, 図参照）がそれぞれ $73 ， 21 ， 6 \%$ であった．次に，この リーフに生息するカニについて広く毒性試験を行なった ところ，上記オウギガニ科 3 種以外にも 4 科 7 種のカニ に STX, neosaxitoxin (neoSTX) が検出され, STX, neoSTX はサンゴ礁域の巻貝，カニに広く分布すること が確認された. さらに, 有毒巻貝 4 種, カニ 2 種のすべ ての胃内容物にはJania sp. が観察され，本石灰藻が摂 食されていることが確認された。 Jania $\mathrm{sp.}$ には鞭毛藻 は付着して捛らず，付近の二枚貝の毒化も見られないの で, 巻貝やカニの PSP の起源は鞭毛藻ではなくJania sp. と考兄られた. Jania sp. はサンゴ礁上ではごく一 般的な海藻であるが，その生育密度は局地変化を示して 


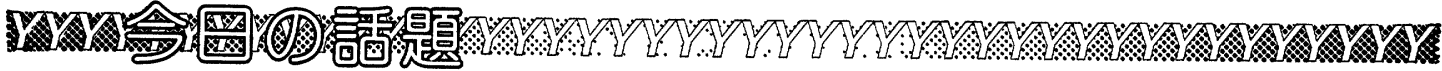

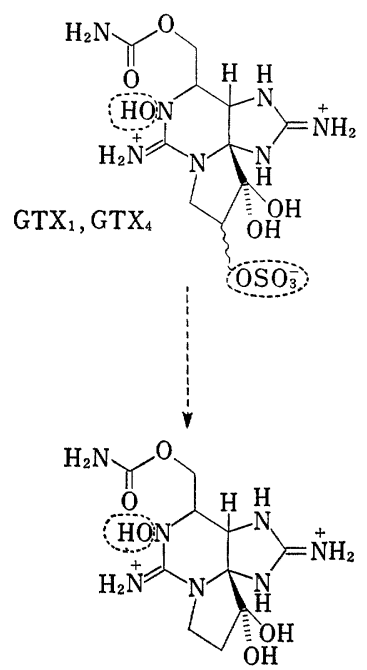

neoSTX

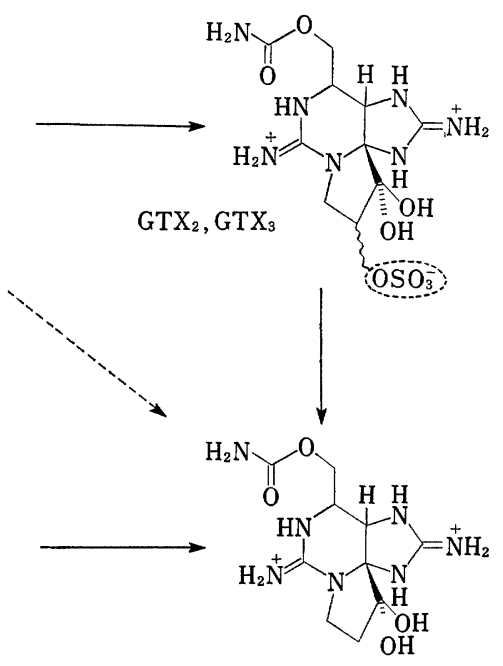

STX

細菌による麻㾝性貝毒の変換

いる. 巻貝やカニの毒性の個体差はこの石灰藻の局地性 を反映していると思われる。

しかし, Jania sp. を起点とする巻貝やカ二の毒化機 構について問題点も残されていた。第一には，Jania sp. の毒は $\mathrm{GTX}_{1 \sim 3}$ から成るのに対し，巻貝やカニでは これらから 11 位の $-\mathrm{OSO}_{3}{ }^{-}$が還元的に脱離した neoSTX や STX が主成分といらことである (図参照). こ の理由として，巻貝やカ二体内での酵素による還元反応 が予想されたため, 有毒ガニ 2 種（スベスベマンジュウ ガニ, ヒメイワオウギガニ）とチョウセンサザェ内臓ホ モジェネートを調製し， $\mathrm{GTX}_{2,3}$ から STX への変換能 を調べた． 静菌剤としてトルエンを添加した系と無添加 の系の 2 種のホモジェネートに $\mathrm{GTX}_{2,3}$ を加えて保温 し，その遠沈上清の毒組成を分析した結果，トルエン無 添加の系のみで $\mathrm{GTX}_{2,3}$ から STX への還元的変換が見 られ，巻貝やカニ自身の酵素ではなく，ホモジェネート 中の細菌による毒の変換の可能性が示唆された.

そこで，上記生物内臓から 分離した 細菌の 培養液に $\mathrm{GTX}_{2,3}$ を加え, 嫌気条件で保温し, GTX $\mathrm{GT}_{2,3}$ から STX への変換能を調べたところ，Alteromonas sp. (OK-1) とVibrio sp. (OK-2) の 2 菌がそれぞれ $30 \%$ と $12 \%$ の変換能を示した. Alteromonas sp. については $\mathrm{GTX}_{2,3}$ の他に $\mathrm{GTX}_{1,4}$, neoSTX, STX を用いても保温試験を 行なった. 毒組成の分析は HPLC一螢光分析に加えてシ
リカゲル TLC，セルロースアセテ 一ト電気泳動も用い，変換生成物の 同定の正確を期した. その結 果, $\mathrm{GTX}_{2,3}$ の 11 位の $-\mathrm{OSO}_{3}{ }^{-}$の還元 的脱離 $\left(\mathrm{GTX}_{2,3} \rightarrow \mathrm{STX}\right.$ の変換) と $\mathrm{GTX}_{1,4}$ および neoSTX の 1 位の $-\mathrm{OH}$ の還元 $\left(\mathrm{GTX}_{1,4} \rightarrow \mathrm{GTX}_{2,3}\right.$, neoSTX $\rightarrow$ STX の変換) が確認され たが，STX は変化を受けなかった。 これで第一の問題は解決したことに なる. 次の問題点, すなわち Jania sp. の毒含量 $\left(0.04 \sim 1.5 \mathrm{MU}^{*} / \mathrm{g}\right)$ に比べてカニの毒含量がきわめて高 い（最高 $660 \mathrm{MU} / \mathrm{g}$ ) 点については, 雑食性のカニが Jania sp. を摂食 した他の生物を慨として効率よく毒を蓄積する可能性 や, 海藻, カ二の共生微生物の関与も考学られ，検討を 行なっている

これまでの結果から，少なくとも紅藻 Jania $\mathrm{sp.} \mathrm{が}$ PSP を含有し，それを摂食した巻貝やカニが毒を蓄積 する際に細菌の働きで PSP の構造変換が起こることが 明らかになった，海藻には硫酸エステル化多糖類が特に 多く ${ }^{(8)}$, 海藻を餌とする巻貝類には硫酸エステル加水分 解酵素も存在する.しかし，本稿で紹介した細菌による PSP の構造変換は加水分解ではなく, N-1 位の $-\mathrm{OH} p$ 11 位の $-\mathrm{OSO}_{3}-$ の還元反応である点で特徴的である.

二枚貝の PSP においても慨料プランクトンの毒組成 との差異が見られるが，アラスカバタークラムを除いて は顕著ではない. 清水ら ${ }^{(2)} は$ ， ホタテガイのホモジェネ 一トを用いて変換実験を行なったが，静菌的条件での実 験は行なっておらず，変換反応を行ならのが細菌か貝自 身の酵素なのか判別できない、また, Sullivan ら(9)はア サリの 1 種にカルバモイル基の分解酵素があると推定し ているが，詳細は明らかでない，細菌による PSP の構 造変換が確認されたのは筆者らの例が初めてと思われ る. 構造変換により安定性と比毒性に差異を生じるた め, 今後の PSP の動態解明においては細菌の役割も考

\footnotetext{
*1 MU (マウスニニット) $: 20 \mathrm{~g}$ のマウス 1 匹を 15 分で死亡 させる毒量
} 
慮することが必要であろう，また，STX は Na チャン ネルの解明試薬として重要であるが，我が国を含めた大 多数の地域で発生する PSP の組成では STX は微量成 分である. 今回の結果は, GTX 群から STX を容易に 調製する有用酵素が得られる可能性を示唆している.

今回 PSP の変換菌として紹介した Alteromonas sp.

は, 偶然にもフグ毒テトロドトキシン生産菌でもあっ た ${ }^{(10)}$. 細菌の多様な機能に驚嘆させられる。

本研究にあたり指導，助言をいただいた東北大学安元健教授， 大島泰克助教授に深謝いたします.

1）橋本芳郎：“魚貝類の書”, 学会出版センター, 1977, p. 42.

2）清水 譲：化学と生物，18，792 (1980).
3) T. Yasumoto: "Toxic Dinoflagellates", ed. by D.M. Anderson, A.W. White and D.G. Baden, Elsevier Science Publishing Co. Inc., New York, 1985, p. 259.

4) 大島秦克: 海洋科学，16，582 (1984).

5) Y. Kotaki, Y. Oshima \& T. Yasumoto: Bull. Japan. Soc. Sci. Fish., 47, 943 (1981).

6) 小瀧裕一: 海洋科学, 16, 594 (1984).

7) Y. Kotaki, Y.Oshima \& T. Yasumoto: "Toxıc Dinoflagellates", ed. by D. M. Anderson, A. W. White and D. G. Baden, Elsevier Science Publishing Co. Inc., New York, 1985, p. 287.

8）西澤一俊 : “海草の生化学と利用”, 恒星社厚生閣, 1983, p. 15.

9) J. J.Sallivan, W. T. Iwaoka \& J. Liston : Brochem. Biophys. Res. Commun., 114, 465 (1983).

10) 安元 健 : 化学と生物, 24, 352 (1986).

(小瀧 裕一，尚䋍女学院短期大学）

\section{ダイズ根粒のセリノール}

\section{—Uptake hydrogenase系の誘導を抑えるリゾビトキシンの前駆体か?}

窒素固定酵素ニトロゲナーゼは, 分子状窒素をアンモ ニアに還元するだけでなく，プロトンも還元して分子状 水素を生成することがよく知られている. Uptake hydrogenase 系 (Hup 系) を持つ根粒バクテロイドでは, ニトロゲナーゼにより生成する分子状水素を再酸化して 窒素固定系の効率化に貢献しているものと考えられてお り，Hup 系は優良ダイズ根粒菌の備えるべき形質の 1 つにあげられている. この点については, 以前本欄にお

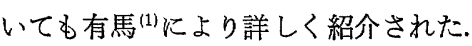

さて，筆者がダイズ根粒の遊離窒素化合物を調べてい たところ, Hup- 株形成ダイズ根粒にしばしば多量の塩 基性未知化合物が集積することを見いだした.この未知 化合物をダイズ根粒より単離精製し同定を行なったとこ ろ,セリノール(2-amino-1, 3-propanediol) であること が判明し，七リノールの構造異性体である 3-amino-1, 2-propanediol (3 APD) も微量成分としてダイズ根粒に 含まれていた(2).

両アミノプロパンジオール（セリノール，3APD） は ダイズ植物体の根粒以外の組織にはほとんど存在せず, また単生ダイズ根粒菌によっても生産されるので, 根粒 内では根粒バクテロイドで生成されているものと考えら れた. 根粒のアミノプロパンジオールの分布を交互接種 群（マメ科植物と根粒菌の組合せ）でみると， ダイズ
群・カウピー群に多量に検出され, エンドウ群・アルフ ァルファ群には検出されず，どらもマメ科植物の根粒に 普遍的に存在する物質ではないらしい.

生体中に遊離のセリノールが存在するという報告は, サトウキビ葉に関する Pinkerton ${ }^{(3)}$ らの報告一報のみで あることが Chemical Abstracts を第 1 巻から調べるこ とによってわかった. 彼らは, サトウキビ葉表面にセリ ノールが存 在 し, 植物病原菌 Helminthosporium sacchari の毒素生産の活性化因子の 1 つであると報告して いる. 遊離の $3 \mathrm{APD}$ についても同様に調べたが，一報 も見あたらなかった，セリノールと $3 \mathrm{APD}$ は，いずれ も㞸素数 3 の単純な構造をしたアミノアルコールである が，生体物質としては両者ともきわめて珍しいアミノア ルュールであることがわかる. Babczinski ら(4)による と, サトウキビ葉では, 解糖系の中間体であるジヒドロ キシアセトンリン酸がトランスアミネーションを受けて セリノールリン酸となり，ホスファターゼによりセリノ ールが生成されているらしい.ダイズ根粒バクテロイド は主に有機酸を呼吸基質として利用し，グルュースなど の糖は利用できないが，ジヒドロキシアセトンリン酸の 前駆体のフルクトース-1,6-二リン酸は呼吸基質として 利用できることが昔から知られている. したがって，ダ イズ根粒でも同様の経路でセリノールが合成されている 


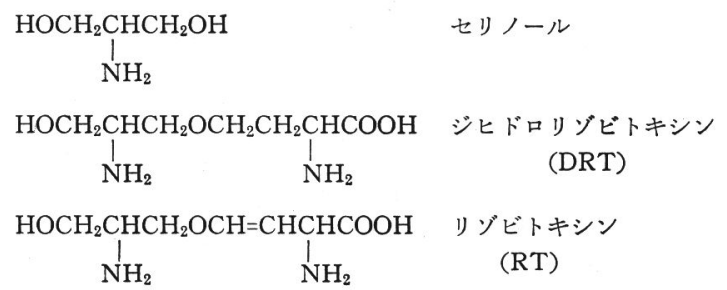

セリンの添加により RT， DRT の 生成量が数倍から十数倍に増え, ま た ${ }^{14} \mathrm{C}$ ーセリノールを添加したとこ ろ, RT, DRT 画分に ${ }^{14} \mathrm{C}$ が入っ た.このような結果より，七リノー ルは RT の前駆体ではないかと考 えられた。

Hup 系は単生菌でも, ニトロゲナーゼより比較的簡 単に誘導することができる. そこで，七リノール， 3 APD， RT，DRT の Hup 系誘導に及ぽす影響を検討し てみたところ， RT は $2 \mu \mathrm{M}$ で Hup 系の誘導を $50 \%$

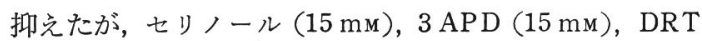
$(500 \mu \mathrm{M})$ では影響がなかった. したがって，RT が根粒 内で生成されると, たとえ遺伝的に Hup 系を保有して いる根粒バクテロイドでも Hup 系が発現しないことも 予想され, RT 生産株がすべて $\mathrm{Hup}^{-}$型となった（表） のは, そのよらな理由もあるのではないかと推定された。 いずれにせよ，セリノールがどのような経路で生合成 されているのか，七リノールが RT の前駆体であるの か，生成された RT が Hup 系の誘導のみを抑えるのか という点について，根粒バクテロイドも用いてさらに詳

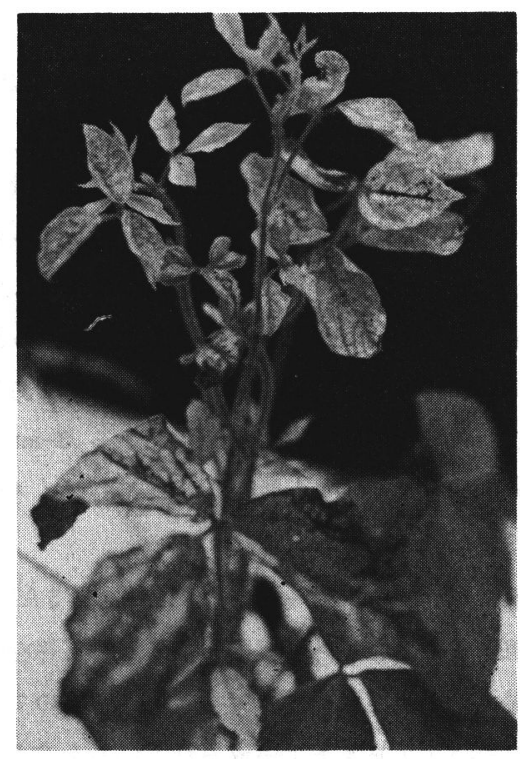

リゾビトキシン生産能の高い根粒菌を接種したタイズ 最上部葉がクロロシス（黄化）を起こし，中位葉がネ クロシスを起こしている. 
しく調べることは，高度に組織化された共生系である根 粒の物質代謝, エネルギー代謝関する私達の理解をさ らに深めてくれるであるう.

1) 有馬泰紘：化学と生物，22，681 (1984).

2) K. Minamisawa \& H. Watanabe : Plant Cell Physiol., 27, 1109 (1986).
3) F. Pinkerton \& G. Strobel : Proc. Natl. Acad. Sci. USA, 73, 4007 (1976).

4) P. Babczinski, U. Matern \& G. A. Strobel : Plant Physiol., 61, 46 (1978).

5) J.S. La Favre \& A. R. J. Eaglesham : Plant and Soil, 92, 443 (1986).

（南 沢 究, 茨城大学農学部資源生物科学科)
プロフィル

石塚 潤西 (Jun j1 Ishizuka) 昭和 7 年 5 月 10 日生 $<$ 略歴>昭和 31 年東北大学 農学部農芸化学科卒業/同年農林省入省 北海道農業試験場勤務 $/ 49$ 年同省農業技 術研究所作物栄美第 3 研究室室長 $/ 58$ 年 農林水産省生物資源研究所空素固定研究 室室長 $/ 62$ 年九州大学農学部農芸化学科 植物栄養肥料学講座教授，現在にいたる く研究テーマと抱負〉マメ科作物の窒素 固定く趣味>野生らんの栽培

小原 進(Susumu Ohara) 昭和22 年11月18日生<略歷>昭和53年東京大学 大学院薬学系研究科修士課程修了 (生命 薬学) /同年北里大学 医学部助手 $/ 61$ 年 同講師，現在にいたるく研究テーマと抱 負 $>$ 胃粘液桾蛋白質の構造之機能, 胃粘 膜上皮細胞の培盖<趣味>散步, 将棋

緒方 隆之 (Takayuki Ogata) 昭和 21 年 9 月 6 日生 一略歷>昭和 44 年九州大 学理学部化学科卒業 $/ 46$ 年同大学大学院 理学研究科修士課程修了後, 德山曹達 (株)に入社, 現在同社藤沢研究所主席研 究員. この間, $52 \sim 54$ 年九州大学工学部 応用化学科汇内地留学く研究テーマと抱 負 $>$ オフフォア, 機能性有機薄膜（生 体膜の機能を 1 つでも合成的に再現する のが夢です）趣味>クラシック音楽， コーラス

大塚 晏央 (Yasuo Ohtsuka) 昭和 18 年 2 月 25 日生 <略歴>昭和 40 年北海道 大学医学部薬学科卒業 $/ 42$ 年同大学大学 院薬学研究科修士課程修了/同年理化学 研究所有機合成化学研究室所属, 气の後 研究員, 現在にいたる.この間, 49 51 年米国シショージア大学 (S. W. Pelletier 教授）留学. 46年薬博く研究テーマと抱 負 $>$ 生物活性中環状天然物の合成<趣 味>クラシック音楽鑑賞, スポーツ（球 技・ただし今は見るだけ)

岡村 直道(Naomichi Okamura) 昭 和25年 1 月 24 日生 $<$ 略歷>昭和 47 年東京 大学理学部動物学教室卒業 $/ 52$ 年同大学 大学院理学系研究科博士課程修了/ 52 54 年日本学術振與会奖励研究員 (東大. 理 - 動物) $/ 55$ 年筑波大学基礎医学系講
師，現在にいたるく研究テーマと抱負〉 哺乳類の精子が精巣上体で運動能, 受精 能を獲得する過程を解き明かしたいく趣 味>山歩き

川崎 勝己(Katsumi Kawasaki) 昭 和31年11月 4 日生<略歴>昭和55年東京 大学薬学部薬学科卒業 $/ 57$ 年同大学大学 院薬学系研究科修士課程修了 $/ 60$ 年同博 土課程修了/同年理化学研究所微生物学 研究室研究員, 現在にいたるく研究テー マ之抱負>遺伝的組換点の生化学. 真核 細胞の染色体の動態，之くに減数分裂時 の DNA と蛋白などの相互作用〈趣味〉 テニス, スキー, 歩きまわること, 観葉 植物

小龍 裕一 (Yuichi Kotaki) 昭和 25 年 7 月 5 日生<略歴>昭和 50 年東北大学 農学部食糧化学科卒業 $/ 52$ 年同大学大学 院農学研究科修士課程修了/同年尚絅女 学院短期大学助手 $/ 53$ 同講師 $/ 60$ 年同助 教授, 現在にいたる. 60 年農博（東北大 学）〈研究テーマと抱負>麻痺性貝毒に 関して，生産から食卓までの毒の動態を 解明したいく趣味>スキー，思いつきで するジョギング，巨人以外が勝った日の プロ野球ニニースを見ること

柴田 武彦 (Takehiko Shibata) 昭 和19年 6 月 15 日生<略歴>昭和 43 年東京 大学理学部生物化学科卒業 $/ 48$ 年同大学 大学院理学系研究科博士課程修了(理博) /同年理化学研究所微生物学研究室 (安 藤忠彦主任研究員) 特別研究生, その後 研究員, 副主任研究員を経て昭和60年よ り同研究室主任研究員, 現在にいたる. この間, 52〜 55年米国エール大学医学校 (ラディング教授)留学く研究テーマと抱 負>遺伝的組換えの機構とその調節.さ らに，相同染色体分離の遺伝的組換え之 の関連，機構を明らかにし，それらの結 果を染色体工学に利用したいく趣味〉機 械修理, 音楽鑑賞

末村 正樹 (Masaki Suemura) 昭和 20 年 6 月 7 日生 $<$ 略歴>昭和 46 年大阪大 学医学部卒業 / 46 49年卒後研修 / 49年 同大学医学部第三内科医員 $/ 56$ 年同助手,
現在にいたる.この間，52〜 54年米国シ ョンスホプキンス大学医学部研究員 $<$ 研 究テーマと抱負〉即時型フレルギーの免 疫学的制御

菅 洋 (Hiroshi Suge) 昭和 7 年12月 9 日生<略歴>1955年東北大学農 学部農学科卒業／同年農林省中国農業試 験場 $/ 1962$ 年同省農業技術研究所 $/ 1978$ 年東北大学農学研究所, 現在同研究所教 授. この間, 1967〜1968年米国カリフォ ルニア大学研究員 / 1976 1977年メキシ 二国立農科大学大学院客員 教 授. 農 博 く研究テーマと抱負〉環境ストレス下に お村る植物の自己防御機構を通じて植物 の環境適応現象を解明したい，宇宙環境 における植物生育の問題にも興味をるっ ているく趣味 > 短歌

高橋 秀幸 (Hideyuki Takahashi) 昭和29年10月 8 日生<略歴>1977年山形 大学農学部園芸学科卒業 $/ 1982$ 年東北大 学大学院博士課程修了(農博) /1985年同 大学農学研究所助手, 現在にいたる. こ の間, 1982 1985 年米国 Wake Forest 大学で Post doctoral fellow<研究テー マと抱負>植物の開花生理, 環境ストレ スと防御機構, 最近は地球環境と宇宙環 境という視点から, 植物の獲得した適応 現象の機構を理解していきたいと考光て いるく趣味〉スキー，山歩き

瀧本 敦 (Atsushi Takimoto) 昭 和 2 年 4 月 9 日生<略歴>昭和 25 年京都 大学農学部農林生物学科卒業/同年同大 学農学部助手 $/ 42$ 年同講師, 次いで同教 授, 現在にいたるく研究テーマと抱負〉 花芽形成誘導機構に関する研究 (花成小 ルモンの実体を明らかにしたい）〈趣 味>音楽鑑賞, 散策

鶴 大 典(Daisuke Tsuru) 昭和 3 年11月 1 日生 <略歷>昭和26年九州大学 農学部農芸化学科卒業／同年大阪市立大 学理学部助手, その後講師, 助教授を経 て，46年長崎大学楽学部教授<研究テー マと抱負>蛋白分解酵素の基礎および応 用研究く趣味〉スポーツ観戦 